\title{
Kopi dan Bauran Pemasaran (Studi Fenomenologi Kedai 9 Cups Coffee and Roastery)
}

\author{
Archie Gredyon, Wulan Purnama Sari \\ archie.gredyon@gmail.com,wulanp@fikom.untar.ac.id
}

Fakultas Ilmu Komunikasi Universitas Tarumanagara

\begin{abstract}
9 Cups Coffee and Roastery is a little coffee shop that not only selling coffee drinks, but they sell some retail coffee beans. The background of this research is started from the significant increasement of coffee shops in Jakarta, based on the datas that writers get from Jakarta Coffee Manual event that presented by Manual Jakarta. This research intended to know how marketing communication strategy that being used in 9 Cups Coffee and Roastery to maintain the business from the increasement of number of coffee shops. To know how the marketing communication strategy that 9 Cups Coffee and Roastery did, writer focused on digging the marketing mix communication which include 4P (price, place, product, promotion) and specifically digging the marketing communication theory that 9 Cups Coffee did. This research is done with qualitative approach with phenomenology method. The key informant in this research are the owner and barista of 9 Cups Coffee and Roastery. In this research, to know how the marketing communication used in 9 Cups writer used interview and participation observation. Can be concluded from this study, the most effective marketing mix that used in 9 Cups Coffee and Roastery is word of mouth marketing communication, caused by many consumers of 9 Cups' products recommend their products to others by posting in social media.
\end{abstract}

Key words: Marketing Communication, Marketing mix, word of mouth, personal selling.

\begin{abstract}
Abstrak
9 Cups Coffee and Roastery adalah sebuah kedai kopi kecil yang tidak hanya menjual minuman namun juga menjual kopi secara retail. Latar belakang penelitian ini dimulai dari jumlah kedai kopi di Jakarta yang mulai bertambah secara signifikan berdasarkan data yang diambil melalui event Jakarta Coffee Manual yang diadakan oleh Manual Jakarta. Penelitian ini bertujuan untuk mengetahui bagaimana strategi komunikasi pemasaran yang dilakukan oleh kedai 9 Cups Coffee and Roastery untuk tetap dapat mempertahankan bisnisnya dari kedai-kedai kopi yang semakin bertambah jumlahnya. Untuk mengetahui strategi komunikasi pemasaran yang dilakukan oleh kedai 9 Cups Coffee and Roastery, penulis berfokus menggali pada teori bauran pemasaran yang mencakup 4P (price, place, product, promotion) dan lebih spesifik dalam menggali komunikasi pemasaran yang dilakukan oleh kedai 9 Cups Coffee. Penelitian ini dilakukan dengan pendekatan kualitatif dengan metode fenomenologi. Key Informant dalam penelitian ini adalah pemilik kedai 9 Cups Coffee and Roastery serta barista yang bekerja di kedai tersebut. Dalam penelitian ini, penulis ingin mengetahui komunikasi pemasaran yang dilakukan oleh 9 Cups Coffee melalui wawancara dan observasi partisipatif. Dapat disimpulkan dari penelitian ini, bauran pemasaran yang paling efektif digunakan oleh 9 Cups Coffee and Roastery merupakan komunikasi pemasaran word of mouth karena banyaknya konsumen produk 9 Cups Coffee and Roastery yang merekomendasikan kembali produk mereka dengan cara posting di media sosial.
\end{abstract}

Kata kunci: Bauran Pemasaran, Komunikasi Pemasaran, word of mouth, personal selling. 


\section{Pendahuluan}

Indonesia adalah salah satu negara produsen kopi terbesar di dunia. Hal tersebut berdampak langsung ke masyarakat Indonesia, menjadikan kopi salah satu minuman pokok yang harus ada di rumah. Mulai dari kopi sachet sampai ke mesin kopi rumahan yang lengkap. Lama-kelamaan keingin tahuan netizen tentang rasa kopi yang lain meningkat sehingga banyaknya kedai kopi yang mulai bermunculan di tahun 2016.

Trend kedai kopi semakin bertambah di tahun 2018 ini. Sejak tahun 2016 sampai sekarang, jumlah coffee shop di Jakarta bertambah dengan pesat. Berdasarkan event Jakarta Coffee Manual yang diselenggarakan oleh Manual Jakarta, setiap tahunnya partisipan kedai kopi di Jakarta semakin bertambah. Jakarta Coffee Manual adalah suatu kegiatan yang berlangsung selama satu bulan untuk mengumpulkan stempel di kedai-kedai kopi yang berpartisipasi di Jakarta dan sekitarnya. Pada tahun 2017, kedai kopi yang berpartisipasi di Jakarta Coffee Manual mencapai 77 kedai, meningkat 27 kedai dari tahun sebelumnya.

Tidak hanya kedai partisipan saja, antusiasme peminum kopi di Jakarta juga sangat tinggi. Banyak yang awalnya hanya penikmat kopi hingga ingin mencoba membuat sendiri dan menjadi seorang homebrewer, yaitu seorang penikmat kopi yang menyeduh sendiri kopi buatannya di rumah ataupun di tempat lain dengan alat seduh manual. Meningkatnya jumlah homebrewer mengakibatkan semakin banyak juga orang yang ingin terjun langsung dan mengenal dunia kopi lebih dalam lagi.

Besarnya komunitas kopi di Indonesia mengakibatkan peminum kopi di Indonesia juga terbagi menjadi first wave, second wave dan third wave coffee drinker.First wave mewakili peminum kopi sachet yang diproduksi secara besarbesaran dan tidak memperhatikan kualitas dari kopinya sama sekali, second wave mewakili peminum kopi yang menyukai kopi bertekstur tebal dengan rasa pahit dan kuat, sedangkan third wave lebih cenderung ke kopi spesialti yang terfokus kepada kualitas biji kopi yang lebih tinggi dan rasa kopi yang cenderung asam dan manis. Sangat banyak peminum kopi gelombang kedua ini yang terkejut dan mengakui bahwa rasa kopi gelombang ketiga sangat unik dan berbeda dengan kopi yang biasanya mereka minum.

Kopi gelombang ketiga ini mengutamakan kualitas hasil produksi biji kopi mulai dari panen sampai disangrainya biji kopi. Biji kopi bisa dinilai berkualitas atau tidak mulai dari green beans atau sebelum biji kopi disangrai. Perhatian yang semakin detail kepada kualitas biji kopi membuat para penikmat kopi juga semakin ingin mengetahui bagaimana seluk-beluk kopi dari ditanam hingga sampai ke cangkir. Perasaan ingin tahu para penikmat kopi membuat beberapa kedai memanfaatkan momentum tersebut dengan membuat area duduk di bar yaitu dimana para peminum kopi dapat berinteraksi dengan barista secara langsung. 9 Cups Coffee and Roastery adalah sebuah kedai kopi kecil yang semenjak awal ingin mengedukasi para peminum kopi terutama para penikmat second wave bahwa kopi tidak selamanya pahit, namun juga memiliki rasa yang unik dan kompleks. Selain itu 9 Cups Coffee and Roastery juga merupakan salah satu kedai kopi partisipan tetap dalam event Jakarta Coffee Manual sejak pertama diselenggarakan.

Namun selain itu ada beberapa hal menarik juga yang dimiliki oleh 9 Cups Coffee. Kedai tersebut merupakan kedai yang bisa dibilang kecil namun dikelilingi beberapa kedai ternama dan masih bisa bertahan. 9 Cups Coffee and Roastery tidak hanya menjual minuman kopi tetapi juga menjual biji kopi lokal maupun 
internasional dengan kualitas yang bisa dibilang sangat baik yang menjadi salah satu kelebihan kedai ini.

Berdasarkan latar belakang di atas, maka rumusan masalah dalam penelitian ini adalah: Bagaimana strategi komunikasi pemasaran yang dilakukan oleh kedai 9 Cups Coffee and Roastery? Penelitian ini dilakukan untuk mengetahui jenis komunikasi pemasaran yang paling berdampak yang dilakukan oleh kedai 9 Cups Coffee and Roastery. Serta ingin mengetahui dampak dari komunikasi pemasaran terhadap penjualan kedai tersebut.

Penelitian terdahulu dilakukan oleh Suherman Kusniadji (2017) dengan judul "Strategi Komunikasi Pemasaran Dalam Kegiatan Pemasaran Produk Consumer Goods (Studi Kasus Pada PT Expand Berlian Mulia Di Semarang)" dengan hasil penelitian menunjukkan kesesuaian antara pola-pola konseptual yang diprediksikan berdasarkan teori-teori yang relevan dengan pola-pola temuan empirik studi kasus.

Kerangka pemikiran utama dalam penelitian adalah konsep bauran pemasaran yang meliputi 4P (price, place, promotion, product) dan menggali lebih dalam pada bauran promosi.

Menurut Kotler (2009), komunikasi pemasaran adalah sarana dimana perusahaan berusaha menginformasikan, membujuk, dan mengingatkan konsumen secara langsung maupun tidak langsung tentang produk dan merek yang dijual. Pada dasarnya, komunikasi pemasaran merepresentasikan "suara" perusahaan dan mereknya serta merupakan saran dimana perusahaan dapat membuat dialog dan membangun hubungan dengan konsumen.

Bauran pemasaran adalah perangkat alat pemasaran yang dapat dikendalikan. 4P yang meliputi produk, harga, distribusi, dan promosi yang dipadukan oleh perusahaan untuk menghasilkan tanggapan yang diinginkan perusahaan dalam pasar sasaran. Variabel-variabel bauran pemasaran yang digunakan dalam penelitian ini adalah 4P yaitu product, place, price, promotion.

Bauran promosi (promotion mix) dibahas lebih lanjut untuk mengetahui lebih dalam stratregi komunikasi pemasaran yang digunakan oleh kedai 9 Cups Coffee and Roastery. Menurut Dharmesta (2008), bauran promosi terdiri dari:

a. Advertising (periklanan) yaitu komunikasi non individu, dengan sejumlah biaya, melalui berbagai media yang dilakukan oleh perusahaan, lembaga atau non-lembaga, serta individu-individu.

b. Sales promotion (promosi penjualan) adalah kegiatan-kegiatan pemasaran selain personal selling, periklanan, dan publisitas, yang mendorong efektivitas pembelian konsumen dan pedagan dengan menggunakan alat-alat seperti peragaan, pameran, demonstrasi, dan sebagainya.

c. Personal selling (penjualan pribadi) adalah interaksi antar individu, saling bertemu muka yang ditunjuk untuk menciptakan, memperbaiki, menguasai, atau mempertahankan hubungan yang saling menguntungkan dengan pihak lain.

d. Direct marketing (pemasaran langsung) adalah sistem pemasaran yang bersifat interaktif yang memanfaatkan satu atau beberapa media iklan untuk menimbulkan respon yang terukur dan/atau transaksi di sembarang lokasi.

Komunikasi word of mouth merupakan proses komunikasi yang berupa pemberian rekomendasi baik secara individu maupun kelompok terhadap suatu produk atau jasa yang bertujuan untuk memberikan informasi secara personal. Komunikasi dari mulut ke mulut merupakan salah satu saluran komunikasi yang sering digunakan oleh perusahaan yang memproduksi baik barang maupun jasa 
karena komunikasi dari mulut ke mulut dinilai sangat berdampak dalam memperlancar proses pemasaran dan mampu memberikan keuntungan kepada perusahaan.

\section{Metode Penelitian}

Metode penelitian yang digunakan oleh penulis adalah metode penelitian kualitatif dengan pendekatan fenomenologi. Penulis terlibat langsung sebagai salah seorang barista di 9 Cups Coffee and Roastery. Hal tersebut menjadikan penulis dapat merasakan langsung bahkan terlibat secara langsung dengan obyek yang diteliti oleh penulis. Dalam penelitian ini penulis memilih penelitian dengan metode kualitatif karena penulis dapat menggali lebih dalam mengenai hal yang ingin diteliti menggunakan metode wawancara mendalam dan observasi.

Pengumpulan Data: Pada penelitian ini, pengumpulan data diperoleh dari hasil observasi, wawancara, dan studi dokumentasi. Data penelitian hasil wawancara dicatat dan direkam melalui teknik pengamatan langsung dan wawancara mendalam. Dokumentasi juga digunakan sebagai teknik pengumpulan data penunjang. Pengamatan dilakukan peneliti terhadap bentuk komunikasi pemasaran yang digunakan baik advertising, sales promotion, personal selling, direct marketing maupun word of mouth. Wawancara dilakukan di kedai 9 Cups Coffee and Roastery pada jam operasional kedai. Key informant penulis adalah pemilik dan barista kedai 9 Cups Coffee and Roastery. Selain key informant, penulis juga mewawancarai salah seorang konsumen tetap dari kedai 9 Cups Coffee and Roastery. Hasil pengamatan dan wawancara yang diperoleh dari key informant kemudian dikumpulkan dan setelah dilakukan reduksi data. Reduksi data adalah proses pemilihan data yang relevan dengan masalah penelitian dan dilakukan terus-menerus selama proses penelitian berlangsung. Pada tahapan ini setelah data dipilih dan disederhanakan, data yang tidak diperlukan diringkas agar memberi penampilan, penyajian serta kesimpulan sementara. Dalam proses analisis data, ketiga tahapan di atas yaitu reduksi data, penyajian data dan verifikasi berlangsung secara bersamaan dengan proses pengumpulan data. Setelah selesai melakukan penyajian data, penarikan kesimpulan dilakukan sebagai suatu kegiatan dari konfigurasi yang utuh.

Triangulasi: Dalam proses memeriksa realibilitas dan validitas data, peneliti menggunakan triangulasi, yaitu menggunakan beberapa metode sekaligus dalam suatu penelitian yang dilakukan secara linear atau secara silang untuk menguji apakah data yang diperoleh dalam penelitian itu adalah sah dan benar (Bungin, 2010).

Dalam penelitian ini, penulis menggunakan teknik triangluasi dengan memanfaatkan penggunaan sumber, berarti membandingkan dan mengecek balik derajat kepercayaan suatu informasi yang diperoleh melalui waktu dan alat yang berbeda, yaitu dengan cara:

1. Membandingkan hasil wawancara pemilik 9 Cups Coffee and Roastery dengan barista untuk mengetahui kebenaran kegiatan komunikasi pemasaran yang dilakukan kedai selama ini.

2. Membandingkan apa yang dikatakan oleh konsumen 9 Cups Coffee and Roastery dengan hasil wawancara key informant untuk mengetahui kebenaran yang didapat oleh konsumen kedai. 
Archie Gredyon, Wulan Purnama Sari: Kopi dan Bauran Pemasaran (Studi Fenomenologi Kedai 9 Cups Coffee and Roastery)

Kerangka Pemikiran:

Gambar 1. Kerangka Pemikiran Penelitian

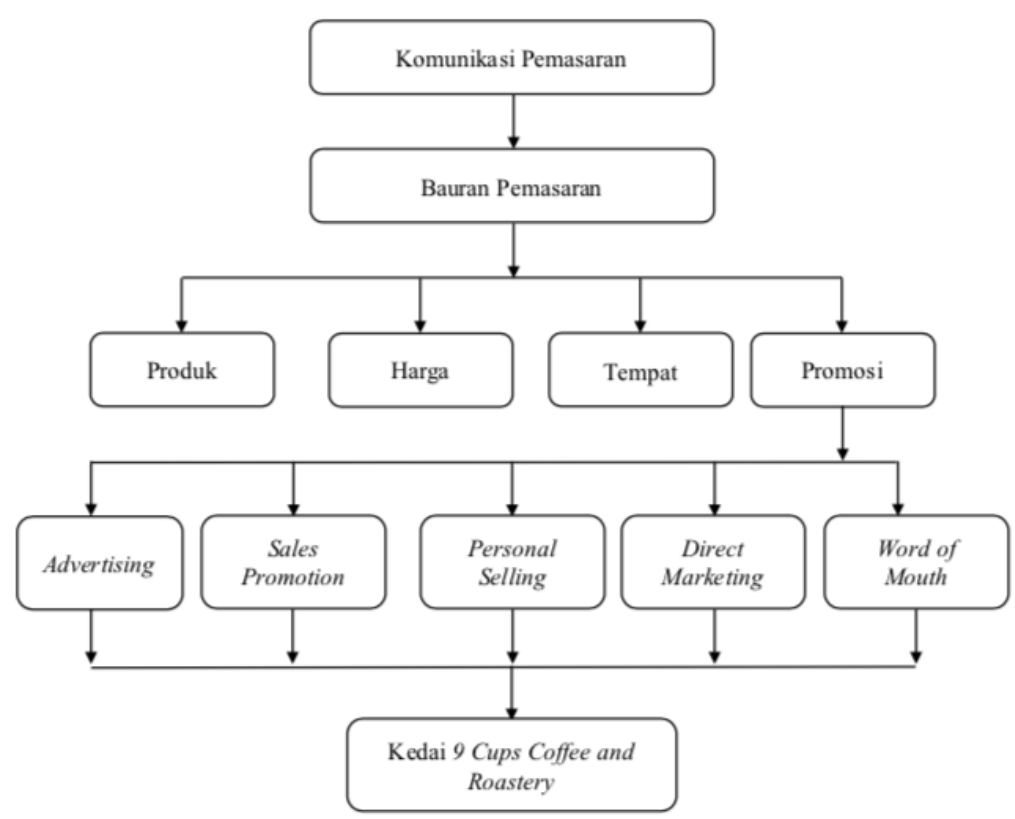

Sumber: Dokumentasi Pribadi

\section{Hasil Temuan dan Diskusi}

Hasil observasi, wawancara mendalam, dan observasi lapangan yang dilakukan oleh penulis terhadap komunikasi pemasaran pada kedai 9 Cups Coffee and Roastery, dapat dikemukakan dalam melakukan kegiatan komunikasi pemasarannya, kedai menggunakan bentuk komunikasi seperti advertsing, personal selling, sales promotion, direct marketing, dan word of mouth.

Kegiatan periklanan yang dilakukan Kedai 9 Cups Coffee and Roastery: Periklanan adalah segala bentuk promosi benda seperti barang, jasa, tempat usaha, dan ide yang disampaikan melalui media dengan biaya sponsor dan ditujukan kepada sebagian besar masyarakat. Iklan adalah salah satu cara yang paling bermanfaat untuk menyebarkan pesan dan untuk membangun preferensi merek.

Iklan yang digunakan oleh 9 Cups Coffee and Roastery dilakukan melalui media sosial Instagram dan Facebook. Namun karena respons positif yang didapat melalui Instagram maka iklan melalui media sosial Facebook sudah tidak berjalan lagi sekarang. Berdasarkan hal tersebut, 9 Cups Coffee and Roastery hanya beriklan melalui media sosial Instagram.

Kegiatan sales promotion yang dilakukan Kedai 9 Cups Coffee and Roastery: Sales promotion adalah kegiatan-kegiatan pemasaran yang mendorong efektivitas pembelian konsumen dan pedagang dengan menggunakan alat-alat seperti peragaan, pameran, demonstrasi, dan sebagainya. Hasil dari observasi dan wawancara yang telah penulis lakukan menghasilkan data bahwa 9 Cups Coffee and Roastery tidak sering melakukan kegiatan promosi.

Kegiatan promosi tahunan yang dilakukan oleh kedai 9 Cups Coffee and Roastery hanya pada saat anniversary kedai yang jatuh di tanggal 26 Oktober. Selain promosi yang diadakan saat anniversary, menurut hasil observasi yang penulis 
lakukan melalui media sosial Instagram @9cupscoffee juga pernah mengadakan promosi untuk mendapatkan merchandise berupa gantungan kunci setiap pembelian biji kopi tertentu.

Kegiatan personal selling yang dilakukan kedai 9 Cups Coffee and Roastery: Personal selling atau penjualan pribadi adalah interaksi antar individu, saling bertemu muka yang ditunjuk untuk menciptakan, memperbaiki, menguasai, atau mempertahankan hubungan yang saling menguntungkan dengan pihak lain. Selama observasi yang penulis lakukan di lapangan sangat sering terjadi kegiatan ini saat proses penjualan dan pembelian di kedai.

Para barista seringkali melakukan rekomendasi kepada para konsumen dan juga melakukan upselling dan menawarkan produk-produk lain sesuai dengan selera konsumen. Sangat banyak interaksi yang terjadi di kedai 9 Cups Coffee and Roastery. Kegiatan personal selling yang dilakukan di 9 Cups Coffee and Roastery bertujuan untuk mempertahankan dan menjaga hubungan baik dengan konsumen dengan harapan konsumen akan kembali ke kedai.

Kegiatan direct marketing yang dilakukan kedai 9 Cups Coffee and Roastery: Direct marketing adalah sistem pemasaran yang bersifat interaktif yang memanfaatkan satu atau beberapa media untuk menimbulkan respon yang terukur dan/atau transaksi di sembarang lokasi. Berdasarkan hasil observasi yang penulis lakukan melalui media sosial Instagrtam @9cupscoffee, kedai ini sudah melakukan peran direct marketing dengan cukup baik karena hampir semua pertanyaan yang menyangkut permasalahan jual beli di kolom komentar terjawab dengan baik. Hal ini membuat para konsumen dimudahkan dengan adanya interaksi yang terjadi antara admin dan juga konsumen.

Kegiatan word of mouth yang dilakukan kedai 9 Cups Coffee and Roastery: Word of mouth adalah proses komunikasi berupa pemberian rekomendasi baik secara individu atau kelompok terhadap suatu produk atau jasa yang bertujuan memberikan informasi secara personal. Berdasarkan hasil observasi yang penulis lakukan melalui media sosial Instagram @9cupscoffee, ada beberapa respon oleh para konsumen yang menyukai produk 9 Cups Coffee and Roastery dan melakukan posting melalui akun pribadinya di Instagram dengan harapan para followers-nya akan melihat dan mengetahui informasi yang diberikan. Berdasarkan hal tersebut, kedai 9 Cups Coffee and Roastery akan terus mempertahankan dan meningkatkan kualitas produk agar rantai word of mouth akan terus berjalan.

Dari beberapa komunikasi pemasaran yang dilakukan oleh kedai 9 Cups Coffee and Roastery, ada satu yang paling dominan digunakan, yaitu komunikasi pemasaran word of mouth. Berdasarkan hasil observasi penulis, produk-produk unggulan kedai 9 Cups Coffee and Roastery yang berupa kopi memiliki kualitas yang cukup baik. Hal tersebut juga didukung melalui postingInstagram para konsumen mereka yang puas dengan produk yang mereka beli. Melalui rekomendasi para konsumen, kedai 9 Cups Coffee and Roastery dapat memperluas jangkauan pasar mereka dan kiat mereka dalam meningkatkan kualitas produk akan semakin tinggi karena Ibu Lidya selaku pemilik menyadari dampak yang ditimbulkan komunikasi pemasaran word of mouth sangat berpengaruh bagi kedai 9 Cups Coffee and Roastery. 


\section{Simpulan}

Dari beberapa bentuk komunikasi pemasaran yang digunakan, penulis menyimpulkan bahwa yang paling dominan digunakan oleh 9 Cups Coffee and Roastery adalah komunikasi word of mouth. Selama kegiatan observasi berlangsung penulis dapat melihat bahwa kegiatan promosi dan iklan cukup jarang dilakukan. Walaupun bentuk komunikasi mulut ke mulut tidak terlihat secara langsung dan signifikan, namun cukup banyak wajah-wajah konsumen baru yang berdatangan ke kedai dan ketika mengobrol mereka mengetahui kedai ini dari temannya yang sebelumnya pernah ke kedai.

Saran:

1. Bagi kedai 9 Cups Coffee and Roastery harus melakukan kegiatan promosi seperti kartu stempel member setiap beberapa pembelian produk mendapatkan 1 produk gratis, dan juga bisa membuat promosi seperti dengan membeli produk dengan harga tertentu akan mendapatkan merchandise dari 9 Cups Coffee and Roastery.

2. Penelitian lanjutan diarahkan kepada strategi komunikasi pemasaran yang bisa digunakan dan juga menggunakan metode kuantitatif untuk mengukur efektivitas dari strategi tersebut.

\section{Ucapan Terima Kasih}

Ucapan terima kasih dihaturkan kepada Wulan Purnama Sari S.Ikom., M.Si. selaku dosen pembimbing yang luar biasa sabar dan pengertian selama membimbing penulis dari awal hingga selesainya penelitian. Lalu penulis juga mengucapkan terima kasih kepada keluarga besar kedai 9 Cups Coffee and Roastery yang memberikan izin kepada penulis untuk melakukan penelitian mengenai kedai kopinya.

\section{Daftar Pustaka}

Kotler, Philip. (2009). Manajemen Pemasaran. Jakarta: Penerbit Erlangga.

Dharmesta. (2008). Manajemen Pemasaran. Yogyakarta: Liberty.

Bungin, Burhan. (2010). Penelitian Kualitatif. Jakarta: Kencana.

Kusniadji, Suherman. (2017). Strategi Komunikasi Pemasaran Dalam Kegiatan Pemasaran Produk Consumer Goods (Studi Kasus Pada PT Expand Berlian Mulia di Semarang). Jurnal Komunikasi, Volume 8 No. 1, 83-98.

https://journal.untar.ac.id/index.php/komunikasi/article/view/49.

https://www.republika.co.id/berita/ekonomi/makro/17/10/01/ox4r5w396-wowindonesia-produsen-kopi-terbesar-keempat-di-dunia

https://manual.co.id/article/manual-jakartas-debut-print-issue-jakarta-coffeemanual-jcm-2017/

https://majalah.ottencoffee.co.id/sejarah-first-second-and-third-wave-coffee/ 